HORTSCIENCE 27(4):341-343. 1992.

\title{
Freezing Tolerance of Avocado Leaves
}

\author{
M.A. McKellar' and D.W. Buchanan ${ }^{2}$ \\ Fruit Crops Department, University of Florida, FL 32611
}

Dewayne L. Ingram ${ }^{3}$

Environmental Horticulture Department University of Florida, FL 32611

\section{C.W. Campbell}

Tropical Research and Education Center, University of Florida, 18905

S. W. 280 St., Homestead, FL 33031

Additional index words. Persea americana, cold acclimation, freezing damage, lethal temperatures, Florida

\begin{abstract}
Freezing tolerance and the lethal freezing temperature were determined for detached leaves of avocado (Persea americana Mill.) by either electrolyte leakage or visual appearance of browning. Leaves from field-grown trees of 'Gainesville', 'Booth8', and 'Winter Mexican' in both Gainesville and Homestead, Fla., were evaluated. All cultivars in both locations survived ice formation in their tissue. Leaf tissue had a temperature limit (lethal freeze temperature) at and below which the tissue died. The lethal freezing temperature varied from -5.1 to $-9.3 \mathrm{C}$, depending on time of year and location. The lethal freeze temperature for a cultivar decreased over the fall and winter as temperatures decreased. Leaves of 'Booth-8' and Winter Mexican' decreased 2.5 and 1.5C, respectively, in Homestead from 13 Nov. 1982 to 5 Feb. 1983. The plants growing at the lower temperature location (Gainesville) had lower lethal freeze temperatures. Leaves of 'Gainesville' had a lethal freeze temperature of - 9.3C from trees at Gainesville and - $7.8 \mathrm{C}$ from trees at Homestead.
\end{abstract}

Avocado trees are known to survive subfreezing temperatures. Previous reports on avocado cold hardiness (Knight, 1974; Manis and Knight, 1967; Scorza and Wilt-

Received for publication 11 Dec. 1990. Accepted for publication; 2 Dec. 1991. Florida Agricultural Experiment Station, Journal Series no. 7917. The cost of publishing this paper was defrayed in part by the payment of page charges. Under postal regulations, this paper therefore must be hereby marked advertisement solely to indicate this fact.

'Present address: 3028 McCarty Hall, IFAS, Univ. of Florida, Gainesville, FL 32611.

${ }^{2}$ Present address: Director, Fort Lauderdale Research and Education Center, 3205 S.W. College Ave., Fort Lauderdale, FL 33314.

${ }^{3}$ Present address: Chairman, Dept. of Horticulture and Landscape Architecture, Agriculture Science Center North, Univ. of Kentucky, Lexington, KY 40506.

${ }^{4}$ Professor Emeritus. bank, 1975) do not indicate whether observed cold hardiness results from supercooling, tolerance of ice formation in tissue, or a combination. The species is divided into three races based on physical characteristics (Bergh, 1975). Cold hardiness of races ranges from most cold hardy (Mexican) to least cold hardy (West Indian), with Guatamalan intermediate. The parentage of many commercial cultivars is unknown, but classification by race is useful given the reported variation in cold hardiness. Characteristics of cultivars used in this experiment suggest that 'Gainesville' is Mexican race, 'Winter Mexican' is a Mexican $\times$ Guatamalan hybrid, and 'Booth- 8 ' is a Guatamalan $\times$ West Indian hybrid.

The objectives of this study were to determine if avocado can survive ice formation in its leaf tissue, determine the lethal freeze temperature below which the leaf tissue dies, 


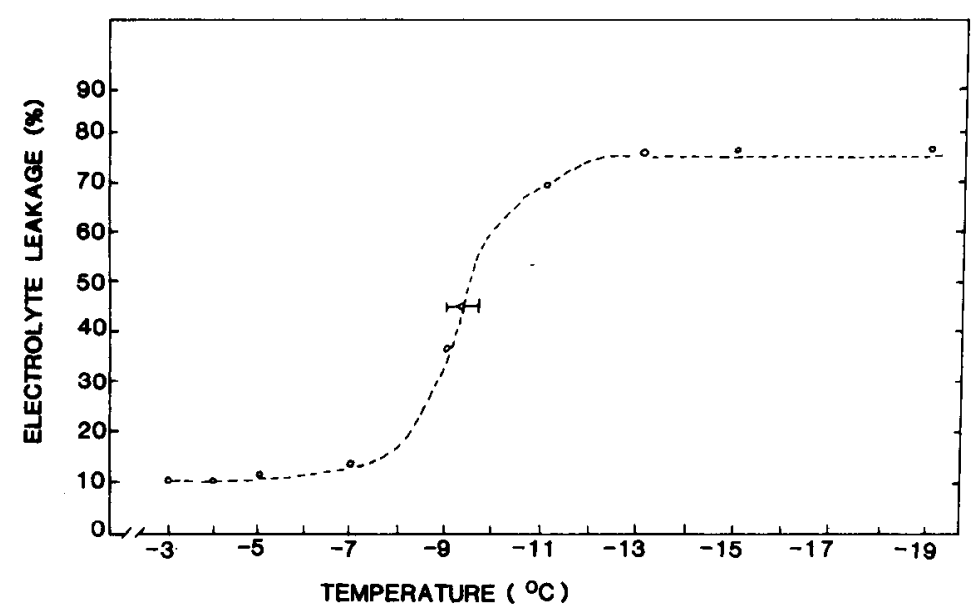

Fig. 1. Electrolyte leakage of 'Gainesville' leaves in Gainesville, Fla., on 31 Jan. 1983, following exposure to different temperatures.

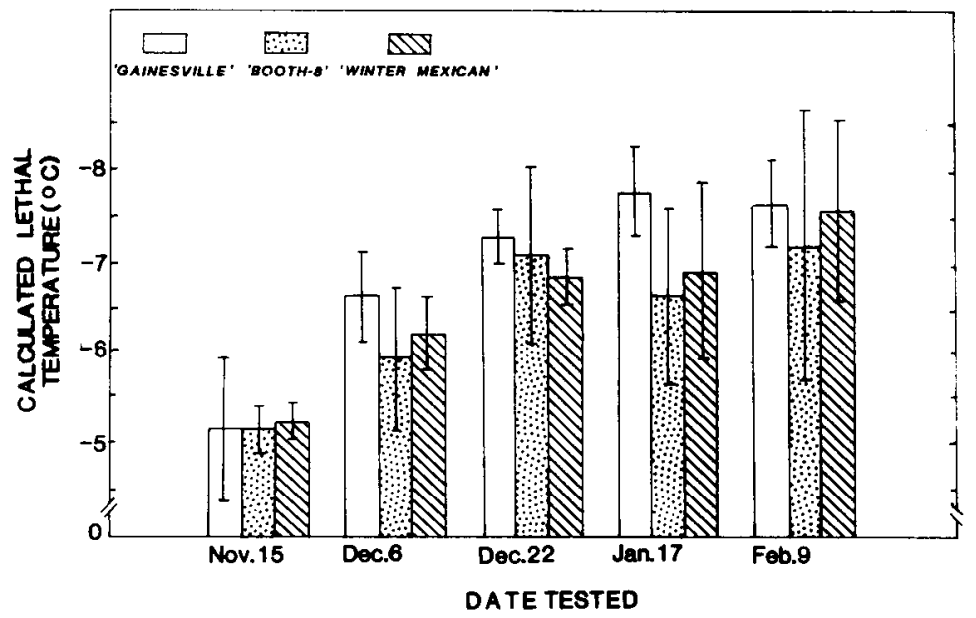

Fig. 2. Calculated lethal temperatures for 'Gainesville', 'Winter Mexican', and 'Booth- 8 ' leaves in Homestead, Fla., on five sampling dates.

and establish if the lethal freeze temperature varies over fall and winter and at different locations.

Mature, field-planted trees of 'Gainesville', 'Winter Mexican', and 'Booth- 8 ' were studied to determine if lethal freeze temperatures varied within one cultivar over the fall and winter. Three trees of each cultivar from the avocado collection at the Tropical Research and Education Center, Homestead, Fla., were sampled from Nov. 1982 to Feb. 1983. Trees grown at Homestead $\left(25.5^{\circ} \mathrm{N}\right.$ latitude) were compared to trees grown at a cooler location at Gainesville, Fla. $\left(29^{\circ} \mathrm{N}\right.$ latitude), to determine if lethal freeze temperature varied with location. Eight trees of 'Gainesville' at Gainesville were sampled on 7 Nov. and 17 Dec. 1982, and on 24 and 31 Jan., 14 Feb., and 15 Mar. 1983. For comparison, three trees of 'Gainesville' at Homestead were sampled on 15 Nov., 6 and 22 Dec. 1982, and on 17 Jan. and 9 Feb. 1983. Six mature terminal leaves at $\approx 1.2 \mathrm{~m}$ above ground level were collected from each of the four tree quadrants (north, east, south, west). Leaves sampled in Homestead were placed inside sealed heavy plastic bags inside an insulated chest containing ice for transport to the laboratory in Gainesville. The principal environmental factor that differed between Gainesville and Homestead was temperature (Table 1). Temperature data for Gainesville $\left(29^{\circ} \mathrm{N}\right)$ were obtained from the Univ. of Florida weather station located within $4 \mathrm{~km}$ of the Gainesville avocado collection site. Temperature data for Homestead were from the Univ. of Florida Tropical Research and Education Center within $0.5 \mathrm{~km}$ of the Homestead avocado collection site.

Damage to avocado leaf tissue as a result of subfreezing temperatures was measured using an electrolyte leakage technique (Anderson et al., 1983 Cooper and Gorton, 1954; Dexter, 1956; Flint et rd., 1967). Leaves were washed in deionized water and placed leaftip down in 75-ret test tubes. Deionized water (1 to $3 \mathrm{ml}$ ) was added to each tube to cover the leaf tip. The tubes were then stoppered and immersed in a glycol-refrigerated bath at $-3 C$. Test tube interior air temperature was monitored (Doric Scientific Trendicator 400 A Type T/F, Doric Scientific Div., Rosemount Inc., San Diego, Calif.) during the experiment with a copper-eonstantan thermocouple inside a stoppered 75-ml pyrex test tube submersed in the glycol bath. Small crystals of ice were dropped into each test tube when the air temperatures of the 75-ml test tube reached $-3 \mathrm{C}$. This procedure caused the deionized water to freeze immediately and ice to nucleate within the leaf tissue and was used to be certain that subsequent viability tests measured the response of leaf tissue that had been frozen. Four test tubes of each cultivar were removed and placed for $1 \mathrm{~h}$ in an ice bath at $0 \mathrm{C}$ to gradually allow the leaf tissue to rise to $0 \mathrm{C}$. Thawed leaves were cut laterally into $1-\mathrm{cm}$ strips, placed into individual test tubes with $30 \mathrm{ml}$ of deionized water, and incubated for $24 \mathrm{~h}$ at 25C. Solutions were then agitated for $15 \mathrm{sec}$ (Vortex-Genie \#12-812, Fisher Scientific, Orlando, Fla.) and electrical conductivity was measured (conductivity meter model CDM3, Radiometer, Copenhagen). The samples were then autoclave for 15 rein, incubated for 24 $\mathrm{h}$ at $25 \mathrm{C}$, agitated again for $15 \mathrm{sec}$, and final conductivity was determined. Electrolytes that leaked into solution after freezing were expressed as a percentage of total electrolytes leached after autoclaving.

The temperature at which leaf tissue did not survive freezing was determined by decreasing the ice bath temperature $1 \mathrm{C} / \mathrm{h}$ down to $-9 \mathrm{C}$. Four test tubes of each cultivar were removed each hour. The test range of -3 to -9C did not include the lethal freeze temperature for 'Gainesville' growing in Gainesville; therefore, one test to temperatures to $-20 \mathrm{C}$ was run on these Gainesville plants on 21 Jan. 1983.

A sigmoid response curve was fitted to the conductivity data for each cultivar, for each test run, using the equation

$$
\begin{aligned}
& \text { percentage of electrolyte leakage }=\mathrm{z}+ \\
& \left((\mathrm{x}-\mathrm{z}) / 1+\mathrm{e}^{-\mathrm{k}(\mathrm{T}-\mathrm{B})}\right)
\end{aligned}
$$

to determine the lethal freeze temperature (critical midpoint temperature); $\mathrm{z}$ is the percentage of electrolyte leakage for nonfrozen leaves; $\mathrm{x}$ is the highest percentage of leakage, $\mathrm{B}$ is the temperature $(\mathrm{C})$ corresponding to the midpoint of the response curve, $\mathrm{k}$ is a function of the slope of the line at the midpoint between $\mathrm{z}$ and $\mathrm{x}$, and $\mathrm{T}$ is the treatment temperature $(\mathrm{C})$. The best fit was determined by least squares (Ingram and Buchanan, 1984). Confidence intervals at a $95 \%$ level of probability were calculated for $\mathrm{B}$ on the fitted electrolyte leakage curve for each cultivar.

The accuracy of the electrolyte leakage test was checked on 31 Jan. 1983, when twice the normal number of leaves of 'Gainesville' from Gainesville were frozen at $-3,-4$, $-5,-7,-9,-11,-13,-15$, or $-19 \mathrm{C}$. Eight leaves were removed at each temperature. Four leaves were treated in the same manner as electrolyte leakage tests. The remaining four, in stoppered moist test tubes, were set aside for 2 days at $25 \mathrm{C}$ and visually observed for development of browning.

In our study, all three cultivars were shown to survive some ice formation within leaf tissue, as indicated by low electrolyte leakage of treated leaf tissue exposed to at least $-5 \mathrm{C}$. In all three cultivars, there was a minimum temperature level below which leaf tissue did not survive freezing. Treatment 
Table 1. Mean monthly high and low temperatures for Homestead and Gainesville, Fla.

\begin{tabular}{|c|c|c|c|c|}
\hline \multirow{2}{*}{$\begin{array}{l}\text { Month and } \\
\text { year }\end{array}$} & \multicolumn{2}{|c|}{ Gainesville } & \multicolumn{2}{|c|}{ Homestead } \\
\hline & High & Low & High & Low \\
\hline & \multicolumn{4}{|c|}{$\operatorname{Temp}\left({ }^{\circ} \mathrm{C}\right)$} \\
\hline Oct. 1982 & 28.1 & 16.0 & 29.1 & 19.7 \\
\hline Nov. 1982 & 26.2 & 14.4 & 27.5 & 17.7 \\
\hline Dec. 1982 & 23.4 & 11.6 & 25.9 & 15.7 \\
\hline Jan. 1983 & 18.4 & 5.5 & 23.3 & 13.4 \\
\hline Feb. 1983 & 20.1 & 7.0 & 23.6 & 13.3 \\
\hline Mar. 1983 & 22.6 & 9.0 & 24.5 & 13.2 \\
\hline
\end{tabular}

Table 2. Calculated lethal temperature based on electrolyte leaching from frozen detached leaves from 'Gainesville' avocado plants growing in Gainesville and Homestead, Fla.

\begin{tabular}{lll}
\hline \hline & \multicolumn{2}{c}{ Lethal temps $\left({ }^{\circ} \mathrm{C}\right)$} \\
\cline { 2 - 3 } Date sampled & Gainesville & Homestead \\
\hline 7 Nov. & $-7.9 \pm 0.4^{z}$ & \\
15 Nov. & & $-5.1 \pm 0.5$ \\
6 Dec. & & $-6.6 \pm 0.7$ \\
17 Dec. & Less than -9 & \\
22 Dec. & & $-7.3 \pm 0.4$ \\
17 Jan. & & $-7.8 \pm 0.4$ \\
24 Jan. & Less than -9 & \\
31 Jan. & $-9.3 \pm 0.3$ & \\
9 Feb. & & $-7.7 \pm 0.5$ \\
14 Feb. & Less than -9 & \\
15 Mar. & Less than -9 \\
\hline
\end{tabular}

${ }^{2}$ Mean $\pm 95 \%$ confidence interval.

temperatures and percent electrolyte leakage for 'Gainesville' leaves harvested on 31 Jan. at Gainesville resulted in a sigmoidal relationship (Fig. 1) that is similar to that found for citrus (Anderson, 1983). Electrolyte leakage was $<10 \%$ for mature 'Gainesville' avocado leaves held at $-3 \mathrm{C}$ for $10 \mathrm{~h}$. These ice-nucleated leaves were visually examined to verify that they had frozen. These samples survived freezing down to $-9 \mathrm{C}$ for $13 \mathrm{~h}$. Maximum electrolyte leakage occurred in winter leaves cooled to $-11 \mathrm{C}$ or more. The midpoint of the response curve was most useful for comparing critical lethal temperatures between cultivars. The calculated midpoint temperature (lethal freeze temperature) was $-9.3 \pm 0.4 \mathrm{C}$ for 'Gainesville' on 31 Jan. 1983.

Avocado leaves may survive winter freezes by freezing avoidance (supercooling) and thus avoid the freezing that follows ice nucleation. The results of our study indicate that avocado leaves tolerated ice formation in their tissue. Figure 1 is based on samples inoculated at $-3 \mathrm{C}$ with ice and that tolerated the ice if temperatures did not drop below $-9 \mathrm{C}$. Plant response in the field may differ, depending on the temperature at which ice nucleation takes place. However, cold hardiness of 'Gainesville' corresponds with the known ranking based on field observations (Krezdorn, 1973).

Leaves of 'Gainesville' exposed to -3 to $-9 \mathrm{C}$, then visually examined after $48 \mathrm{~h}$ at $25 \mathrm{C}$, remained green, while those exposed to $-11 \mathrm{C}$ or lower turned brown. This lethal temperature is in agreement with the critical lethal temperature calculated from the electrolyte leakage data. Electrolyte leakage seemingly provides a good indication of lethal temperatures for avocado leaves.

The lethal freeze temperature decreased for the three cultivars over the fall and winter. 'Gainesville', 'Winter Mexican', and 'Booth8 ' leaves from Homestead acclimated $\approx 2 \mathrm{C}$ ( -5 to $-7 C$ ) from 15 Nov. to 9 Feb. (Fig. 2 ). This increase in cold hardiness coincided closely with the decrease in monthly mean day and night temperatures in Homestead during this period. Cold hardiness increased in citrus exposed to prolonged cool night temperatures (Young and Peynado, 1962).

Trees of 'Gainesville' growing at Homestead in southern Florida and at the cooler location of Gainesville in north central Florida had different lethal freeze temperatures during the same period. 'Gainesville' leaves in Gainesville increased in cold hardiness from $-7.9 \pm 0.4 \mathrm{C}$ to $-9.3 \pm 0.3 \mathrm{C}$ from 7 Nov to 31 Jan. (Table 2) and were below $-9 \mathrm{C}$ from 17 Dec. 1982, until 15 Mar. 1983. During the same period, 'Gainesville' leaves in Homestead increased in cold hardiness from $-5.1 \pm 0.5 \mathrm{C}$ to $-7.8 \pm 0.4 \mathrm{C}$. Air temperatures in Gainesville dropped lower and increased more slowly in spring than did the temperatures in Homestead (Table 1). This investigation did not determine maximum cold hardiness throughout the year. Except for the test run on 31 Jan., no tests were executed below -9C. The critical lethal temperature for 'Gainesville' in Gainesville was below
-9C on test dates 17 Dec., 24 Jan., 14 Feb., and 15 Mar. and thus is listed as less than $-9 \mathrm{C}$ in Table 2.

Our study indicates that avocado leaves can tolerate ice formation in their tissues if a critical minimum lethal temperature is not exceeded. This lethal temperature varies in response to environment.

\section{Literature Cited}

Anderson, J.R. 1983. Ice nucleating agents involved in freezing of plant tissues. PhD Diss., Univ. of Florida, Gainesville.

Anderson, J. R., D.W. Buchanan, R.E. Stall, and C.B. Hall. 1982. Frost injury of tender plants increased by Pseudomonas syringae van Hall. J. Amer. Soc. Hort. Sci. 107:123-125.

Bergh, B.O. 1975. Avocados, p. 541-567. In: J. Janick and J.M. Moore (eds.). Advances in fruit breeding. Purdue Univ. Press, West Lafayette, Ind.

Cooper, W.C. and B.S. Gorton. 1954. Freezing tests with small trees and detached leaves of grapefruit. Proc Amer. Soc. Hort. Sci. 63:167172.

Dexter, S.T. 1956. The evaluation of crop plants for winter hardiness. Advances in agronomy, vol 8. Academic, New York. p. 203-236.

Flint, H. L., B.R. Boyce, and D.J. Beattie. 1967. Index of injury-a useful expression of freezing injury to plant tissues as determined by the electrolyte method. Can. J. Plant Sci. 17:229-230.

Ingram, D.L. and D.W. Buchanan. 1984. Lethal high temperatures for roots of three citrus rootstock. J. Amer. Soc. Hort. Sci. 109(2):189193.

Knight, R. J., Jr. 1974. The potential of cold-tolerant avocado introductions in breeding for enhanced winter hardiness. Proc. Fla. State Hort. Soc. 87:348-353.

Krezdorn, A.H. 1973. Influence of rootstock on cold hardiness of avocados. Proc. Fla. State Hort. Soc. 86:346-348.

Manis, W.E. and R.J. Knight, Jr. 1967. Avocado germplasm evaluation technique used in screening for cold tolerance. Proc. Fla. State Hort. Soc. 80:387-391.

Scorza, R.S. and W.J. Wiltbank. 1975. Evaluation of avocado cold hardiness. Proc. Fla. State Hort. Soc. 88:496-499.

Young, R.H. and A. Peynado. 1962. Growth and cold-hardiness of citrus and related species when exposed to different night temperatures. J. Amer. Soc. Hort. Sci. 81:238-243. 